\title{
Does service innovation matter? An empirical study on market orientation and supply chain performance
}

\author{
T-Y. D.J. Cheng ${ }^{*}$ and C-H. V. Chen \\ No. 300, Jhongda Rd., Jhongli City, Taoyuan County 32001, Taiwan, R.O.C. \\ *To whom all correspondence should be addressed \\ djcheng101@gmail.com
}

Graduate School, Department of Business Administration, National Central University, Taiwan, R.O.C.

\begin{abstract}
The objective of this study was to explore how firm service innovation mediates market orientation and business performance. This paper begins with a literature review indicating the themes from which we developed our conceptual framework. Structural equation modeling based on a cross-section $(n=260)$ of 5 years of supply chain business data (2009-2013) in Greater China was conducted. We concluded that firm market orientation and service innovation exert significantly positive effects on business performance. In addition, the results supported our model that market orientation is mediated by the effect of service innovation on business performance. Market orientation and service innovation had a stronger combined effect on business performance than market orientation alone did. This paper provides implications for how firms can be more effectively synergized amid challenges and gain a competitive advantage in the global supply chain.
\end{abstract}

\section{Introduction}

Christopher (2000) suggested that a supply chain is a linkage of firms that engage in various activities and create valued products and services delivered through a conduit to the ultimate customers. Essentially, the modern supply chain is characterized by volatile and unpredictable demand and has become more dynamic and complex (Berry, Whybark \& Jacobs, 2005; Bowersox, Closs \& Cooper, 2002). Therefore, supply chain has increased the difficulty for firms in enhancing business performance (Cohen, 2001; Christensen, 2013; Christopher, 2000; Teece, 2010).

More importantly, the supply chain signifies several new challenges in the areas of cost performance, order fulfillment, and service agility. This creates pressure for firms because they cannot always employ a conventional set of skills to generate business opportunities in the future. All organizations, regardless of business and operation type, should seek high customer satisfaction as their first priority.

In their efforts to achieve high levels of customer satisfaction, firms are increasingly aware that they should adapt by examining how effectively organizations and individuals use acquired knowledge to create competitiveness within their environment. Over time, a paradigm shift toward a businesswide system that integrates organizational structures, systems, and skills enables a business to consistently improve the value provided to customers and has become a central goal for all supply chain firms.

More specifically, a study by Morgan, Vorhies and Mason (2009) asserted that market orientation provides a solid foundation for firms to create customer-driven capabilities around the world. For this purpose, firms must transform competency into company-specific skills that are deeply rooted in the service chain and strategically valued for customer satisfaction throughout the market. When firms have more business-specific skills, they can be more innovative and competitive. Any organization that fails to innovate risks losing value creation in the future (Christensen, 2013; Weerawardena, 2003). Service innovation tends to be reinforced only when firms support learning and foster customer satisfaction when providing all types of services (Calantone, Cavusgil \& Zhao, 2002; Wang, 2008).

According to foregoing arguments, several discussions have linked market orientation and services to enhancing business performance in various industries. However, to our knowledge, research exploring the mediating effect of service innovation on market orientation and business performance in supply chain businesses remains insufficient. As China has become increasingly crucial to the worldwide economy, studies on supply chains in this country have attracted more attention (Zhao, Flynn \& Roth, 2007). Furthermore, Chow, Madu, Kuei, Lu, Lin and Tseng (2008) asserted that Taiwan has extensive operations in Greater China and is now a major player in the worldwide information and communication technology supply chain. Zhu, Sarkis and Geng (2005) also proposed the key role that China and Taiwan play in supply chain activities. From a value-chain perspective, the supply chain business in Greater China is an appropriate sample for validating the mediating effect of service innovation between market orientation and firm performance.

In summation, this article has two primary objectives: (1) to fill the research gap by integrating a framework that links firm performance during market orientation and service 
innovation to performance; (2) to clarify the potential implications of service innovation for practice and how service innovation allows supply chain businesses to increase their competitiveness in the market.

\section{Literature review and hypothesis development}

\section{Market orientation and firm performance}

Over the past few years, firms have attempted to achieve sustained performance in the midst of fierce global competition, which has drawn increasing attention to supply chains. Market orientation refers to a business approach that concentrates on identifying and fulfilling the actual needs of customers (Kirca, Jayachandran \& Bearden, 2005; Kotler, 2002). Kohli and Jaworski (1990) asserted that market intelligence, dissemination of this intelligence among organizations, and rapid satisfaction of customer needs tends to be prioritized over market success. Similarly, Narver and Slater (1990) argued that market orientation is a cornerstone for firms and should be embraced through positive behavior in value creation efforts, enabling firms to provide valuable services for customers, thus improving business performance.

For the purpose of enhancing service fulfillment, market orientation enables businesses to be focused and competitive when various departments are fully engaged and coordinate with one another to support the delivery of quality services to promote the interests of their customers (Langerak, Hultink \& Robben, 2004). Specifically, market-oriented firms typically commit to providing value for customers. Satisfied customers are more likely to engage in sustained business transactions than unsatisfied customers.

Therefore, firms should carefully seek customer-centric programs to help identify unrealized customer value and determine how customer satisfaction could be effectively reinforced. Thus, firms should be more aware of competitor activities in advance and mitigate possible risks in launching new operations or services in the market to increase competitiveness (Lukas \& Ferrell, 2000; Ramani \& Kumar, 2008).

Transforming market knowledge through innovation to increase service quality is imperative for modern businesses (Calantone et al., 2002). Furthermore, Drucker (2007) emphasized that the strategic role of firm innovation through knowledge diffusion, which results in high business performance, has gained more attention. Innovation is imperative to increase competitiveness in the current changing business environment. However, developing an effective innovation capability to increase market competitiveness is not an easy task for any business. By contrast, firms must learn by increasing the level of innovation according to their past performance to create value for customers (Dishman \& Pearson, 2003).

To achieve superior performance, companies must develop business-specific skills through learning and collaboration among various organizational units. In addition, researchers
(Kandampully \& Duddy, 1999; Ramani \& Kumar, 2008) have hypothesized that market-oriented firms have more business-specific skills, which can be used to anticipate market changes and customer preferences, than firms that are not market-oriented. A study by Szymanski, Kroff and Troy (2007) found that interfunctional coordination within organizations intended to enhance new product success was directly associated with firm innovation and market orientation.

Market-oriented businesses tend to create valuable services for customers and commit to long-term firm success (Kirca $e t$ al., 2005; Langerak et al., 2004). Therefore, we propose the following:

Hypothesis 1: Market orientation positively relates to
business performance.

\section{Market orientation and service innovation}

Slater and Narver (1993) asserted that service innovation is a necessary strategy for long-term firm success. Moreover, Green and Scotchmer (1995) argued that innovation is a multidimensional process through which firms gradually alter their processes of service delivery to increase customer satisfaction. However, successful service innovation is difficult to sustain because firms operating in highly competitive markets are likely to change. Thus, more firms have adopted innovative strategies and practices to increase customer involvement in innovation, and these strategies are now a vital part of enhancing businesses worldwide (Chapman et al., 2003).

Service innovation is a broad term that refers to firm focus on operations, services, and delivery to anticipate changes on the business forefront (Langerak et al., 2004). The innovation capability operations in which firms engage are composed of technical and administrative innovation (Daft, 1982; Damanpour, 1991). More specifically, technical innovation pertains to core organizational processes that typically involve the use of technology to create value-added services for customers. Administrative innovation refers to efforts to indirectly support creating value for customers through management activities and organizational structures.

According to Avlonitis, Papastathopoulou and Gounaris (2001) as well as Fruhling and Siau (2007), innovation may refer to an operation, a process, a modification, or service delivery that is perceived as novel in a business, organization, or market. In addition, Weerawardena (2003) suggested that innovation is an adjustment of marketing systems, processes, product services, or organizational systems to enhance customer satisfaction through value creation.

On the basis of the foregoing arguments, an increasing number of studies have focused on innovation that results in the success of new services (Avlonitis et al., 2001; Stank, Keller \& Daugherty, 2001; Vickery, Jayaram, Droge \& Calantone, 2003). According to Matear, Osborne, Garrett and Gray (2002), the relationship between market orientation and 
innovation has received continuous attention. Hence, Hult and Ketchen (2001) hypothesized that market orientation, which is an essential marketing capability, enables firms to gain competitiveness and achieve superior performance. To remain competitive, firms must work comprehensively to attract more attention from customers through the increased integration of service innovation and anticipate market changes faster than competitors do.

Thus, firms are more capable of seamlessly integrating functions within organizations, which tends to allow for the possibility and sustainability of service innovation (Gray \& Hooley, 2002; Grinstein, 2008). According to the foregoing arguments, we propose the following:

Hypothesis 2: Market orientation positively relates to service innovation

Service innovation, market orientation, firm performance, and mediation effect

An increasing number of arguments regarding market orientation and service innovation leading to business performances have become critical in business strategy (Avlonitis et al., 2001; Matear et al., 2002; Porter, 2008; Weerawardena, 2003). Consequently, firms must adopt greater innovation, including new operations, services, customers, and markets, to remain competitive (Avolnitis et al., 2001). According to Kirca et al. (2005), firms cannot be successful when innovation to increase customer satisfaction and competitiveness is absent during market orientation.

When external involvement in the creation of customer service is incorporated with internal administration and technological innovation, high performance in supply chains tends to be created and sustained (Rodrigues, Stank \& Lynch, 2004; Stank, Keller \& Daugherty, 2001). More importantly, service innovation leading to business success can be achieved through the involvement of external customers in every order fulfillment process. Thus, valuing market orientation highly and transforming market changes into service innovation are the most critical capabilities in value creation and tend to have high financial rewards.

Firms can deliver products or services with shorter lead times, superior quality, and improved cost performance that customers perceive as truly beneficial to achieve market competitiveness. Specifically, effectively integrating service innovation within organizations enhances the flow of operations and quality performance, which eventually increases customer loyalty and sales (Hart, 2006). Firms that seamlessly integrate all resources and systems internally and externally tend to be innovative and generate more effective solutions to business problems (Brown, 2007).

Furthermore, Eppinger (2001) maintained that faster innovation in response to market changes tended to positively affect firm competitiveness. The advantage of service innovation is that firms engaging in this innovation focus more on increasing business efficiency through their operational structures. Service offerings to customers that are driven by innovation tend to increase firms' market competitiveness (Gainer \& Padanyi, 2005; Homburg \& Pflesser, 2000). Consequently, service innovation can be reflected in goal alignment, business sustainability, and bottom-line numbers (Moore, 2004).

Thus, service innovation benefits firms and customers. Customers tend to buy more products from firms with service-driven approaches than they do from firms without these approaches. Faster responses to market changes tend to foster service agility and thus improve firm competitiveness, increasing business revenue.

In summation, organizations may improve business performance through the adoption of firm innovativeness followed by firm-wide system integration. According to the foregoing arguments, we propose the following:

Hypothesis 3: Service innovation positively relates to firm performance.

Hypothesis 4: Service innovation mediates the relationship between market orientation and firm performance.

\section{Research method and data}

\section{Conceptual framework}

Based on the research objectives and literature review, we developed the conceptual framework shown in Figure 1, integrated several different theoretical perspectives, namely market orientation, service innovation and the business performance of supply chain firms. The framework serves to examine the relationship between market orientation and service innovation on supply chain business performance.

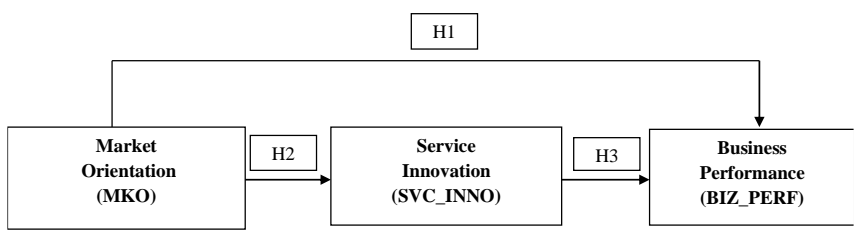

\section{Figure 1: Conceptual framework}

\section{Sample and data}

A sample of 350 companies associated with supply chain business was gathered from the Taiwan Stock Exchange (TWSE). The targeted companies with operations in Taiwan and China were considered better-managed. A two-part coded questionnaire with a cover letter explaining the purpose of the study and assuring participants' strict anonymity was sent to the sample companies in January 2014. The first part was a generic questionnaire related to market orientation (MKO) and service innovation (SVC_INNO) to be answered by the director of marketing and sales. The second part was a specific questionnaire related to business performance that was to be filled out by the director (or manager) of finance. 
All responses were confirmed by a thank-you note to the respondents. For answers completed by two respondents, possible misinterpretation resulting from common method variance was avoided to the extent possible.

Following three e-mails and phone reminders, a total of 287 questionnaires were received in August 2014, resulting in a $82 \%$ response rate. Surveys with incomplete and missing responses were removed from the study, which reduced the final sample size to 260 responses $(74.3 \%)$, all of which were subsequently used in this study. Based on the argument of Baruch and Holtom (2008), the average response rate in this research, which exceeded $50 \%$, was acceptable. Five types of supply chain businesses were analyzed: procurement $(19.23 \%)$, manufacturing $(42.31 \%)$, transportation $(11.54 \%)$, distribution \& retailing $(17.30 \%)$, and others $(9.62 \%$; covering those companies in material handling, packaging, inventory management, order fulfillment, and customer service \& information), which comprised a total of 260 companies.

\section{Questionnaire}

The questionnaire in this study was compiled based on a multidimensional measurement combined with the aforementioned observable items. The questionnaire was composed of four demographic questions. The rest of the sections, which consisted of 27 items, were as follows: 9 items were used to measure market orientation (MKO), 13 items were used to measure service innovation (SVC INNO), and 5 items were used to measure business performance. The data were collected using a 7-point Likert scale in this study. The answers were measured with 1 denoting strongly disagree and 7 denoting strongly agree.

The sources of the questionnaire and construct validity as well as reliability are summarized in Table 1 . As a test rule to verify internal consistency and reliability, Cronbach's $\alpha$ test on data should be greater than 0.70 based on the argument of Cronbach (1970). Moreover, the AVE must be greater than 0.50 for an observable variable's explainable variance to exceed the measurement error (Hair, Rolph, Ronald \& William, 1998). The numbers in Table 1 suggest that the Cronbach's $\alpha$ test was greater than 0.7 , and all the AVEs were greater than 0.5 in this study. Consequently, the data in this study had adequate reliability and convergent validity.

Table 1: Model construct, reliability and convergent validity

\begin{tabular}{|c|c|c|c|c|c|c|}
\hline Construct & items & & Sources & Cronbach's Alpha & $\mathrm{CR}$ & AVE \\
\hline \multirow{3}{*}{$\begin{array}{l}\text { Market } \\
\text { orientation }\end{array}$} & 9 & Langerak et al. & 1. Customer orientation & .762 & .768 & .525 \\
\hline & & 2004 & 2. Competitor orientation & .788 & .787 & .555 \\
\hline & & & $\begin{array}{l}\text { 3. Inter-functional } \\
\text { coordination }\end{array}$ & .837 & .861 & .678 \\
\hline \multirow[t]{4}{*}{$\begin{array}{l}\text { Service } \\
\text { innovation }\end{array}$} & 13 & $\begin{array}{l}\text { Avlonitis et } \\
\text { al. } 2001\end{array}$ & $\begin{array}{l}\text { 1. Operation/ } \\
\text { delivery process newness }\end{array}$ & .820 & .838 & .567 \\
\hline & & & $\begin{array}{l}\text { 2. Service } \\
\text { modification }\end{array}$ & .857 & .858 & .668 \\
\hline & & & $\begin{array}{l}\text { 3. Service newness } \\
\text { to the market }\end{array}$ & .745 & .747 & .500 \\
\hline & & & $\begin{array}{l}\text { 4. Service newness to the } \\
\text { company }\end{array}$ & .747 & .756 & .511 \\
\hline $\begin{array}{l}\text { Business } \\
\text { performance }\end{array}$ & 5 & \multicolumn{2}{|c|}{$\begin{array}{l}\text { 1. Oke (2007) and Wang (2008) for profit and } \\
\text { sales growth. } \\
\text { 2. Zailani and Rajagopal (2005) for quality and } \\
\text { time to market. } \\
\text { 3. Rao and Rao (2009) for inventory turn. }\end{array}$} & .856 & .854 & .540 \\
\hline
\end{tabular}

Then, a cross-sectional analysis was administered to analyze the direct effect of $\mathrm{MKO}$ on BIZ_PERF as well as the mediating effect of MKO on SVC_INNO and BIZ_PERF. For this study, all variables are defined as follows:

\section{Market orientation}

Nine items in customer orientation (CUS), competitor orientation (COM), and inter-functional coordination (IFC) were adopted from the questionnaire suggested by Langerak et al. (2004). A higher score indicated that a firm favored more market orientation over a 5-year period (2009-2013).

\section{Service innovation}

Thirteen items in operation/delivery process newness (ODP), service modification (SM), service newness to the market (SNM), and service newness to the company (SNC) were adopted from the questionnaire developed by Avlonitis et al. (2001). The questionnaire's item list was not exhaustive, but the major items were included in the list. The questionnaire measured how effectively service innovation was implemented to support market orientation and business performance by sample companies over a 5-year period (2009-2013). 


\section{Business performance}

Business performance indicates the effectiveness of operations, quality, and service of a firm achieves. The goals measured in this research are formative and considered key performance indicators or crucial to company success. More specifically, a number of performance measures on financial (e.g., sales and profitability) and non-financial (e.g., quality, inventory turn, and time to the market) are manageable in supply chain management (Rao \& Rao, 2009; Zailani \& Rajagopal, 2005). In this study, five key indicators are used, which are listed in this research to measure the supply chain business of companies surveyed over a 5-year period (20092013).

\section{Control variables}

Earlier researchers (Chatterjee \& Wernerfelt, 1991) have considered firm age and capital to be organizational and operation-based variables. Furthermore, plant location and the number of hired employees at each firm are also thought to affect business operations. Therefore, firm age, capital, location, and the number of personnel likely influence spending on innovation, lead time enhancement, cost performance, and attainment of business goals (Geringer, Tallman \& Olsen, 2000). Consequently, these four variables were considered controlled in this study.

\section{Model fit indices}

In this research, structural equation modeling was used to test the causal relationships among variables. The statistical software SPSS and AMOS 21.0 were used, and the maximum-likelihood estimation method was deployed. The model fit was assessed using Chi-square $\left(x^{2}\right)$ and goodnessof-fit index (GFI) . The value for $x^{2} / \mathrm{df}$ should be less than 2.0 (Jöreskog \& Sörbom, 1996; Premkumar \& King, 1994) to test the absolute fit of the model. Additionally, the values of the GFI and CFI should exceed 0.90 (Bentler, 1992) for the sake of model consistency. The model fit indices were $x^{2}=369.36$, Normed $\chi\left(\chi^{2} / \mathrm{df}\right)=1.18$, and $p<.001(\mathrm{RMSEA}=.03 ; \mathrm{GFI}=.91$; $\mathrm{AGFI}=.90 ; \mathrm{CFI}=.99 \mathrm{NFI}=.91 ; \mathrm{IFI}=0.99)$. Therefore, the construct and measures shown in this study reflected a good fit in model.

\section{Model construct and representation}

Figure 2 shows that each factor loading was greater than 0.5 , and the model construct was a good fit, as it met the criteria of Bagozzi and Yi (1988). All factor loadings in each hypothesis in this study were fully examined and are presented in Figure 2. In addition, standardized loadings for each measurement item are shown in Table 2.

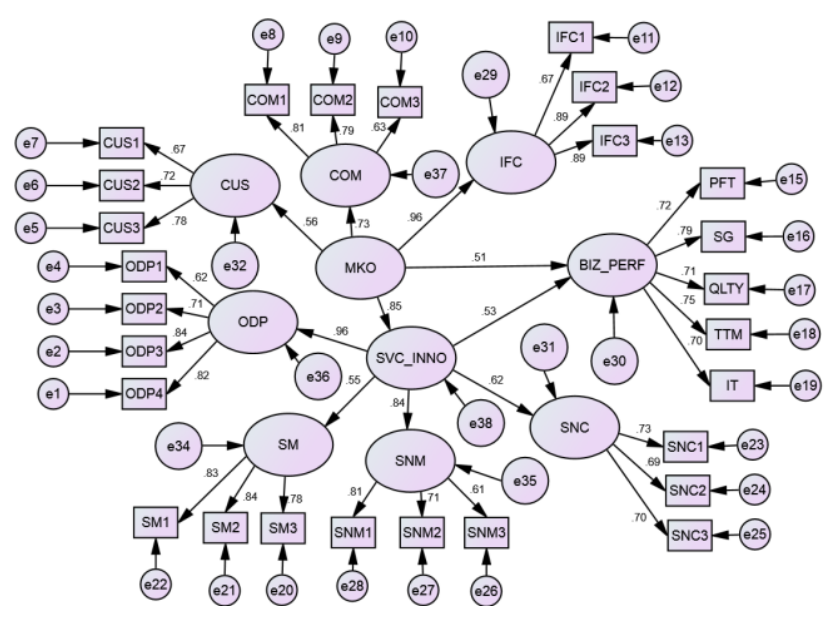

Figure 2: Factor loadings and path analysis in model construct

Notes:

1. MKO stands for market orientation; CUS stands for customer orientation COM stands for competitor orientation and IFC stands for interfunctional coordination.

2. SVC_INNO stands for service innovation; ODP stands for Operating/delivery process newness; SM stands for service modifications; SNM stands for service newness to the market and SNC stands for service newness to the company.

3. BIZ_PERF stands for business performance; PFT stands for profit; SG stands for sales growth; QLTY stands for quality; TTM stands for time to the market and IT stands for inventory turn. 
Table 2: Estimates of standardized regression weights

\begin{tabular}{|c|c|c|c|}
\hline Construct & & Measurement Item & Standardized \\
\hline \multirow{9}{*}{$\begin{array}{l}\text { Market } \\
\text { orientation }\end{array}$} & $\begin{array}{l}\text { Customer } \\
\text { orientation }\end{array}$ & $\begin{array}{l}\text { CUS1. Our firm consults customers to improve the quality of } \\
\text { service. }\end{array}$ & 67 \\
\hline & (CUS) & CUS 2. Our firm looks for ways to offer customers more value. & .72 \\
\hline & & CUS 3. Our firm treats customers as partners. & .78 \\
\hline & $\begin{array}{l}\text { Competitor } \\
\text { orientation }\end{array}$ & $\begin{array}{l}\text { COM1. Our firm knows how competitors maintain relationships } \\
\text { with customers. }\end{array}$ & .81 \\
\hline & $(\mathrm{COM})$ & COM2. Our firm knows why customers switch to competitors. & .79 \\
\hline & & $\begin{array}{l}\text { COM3. Our firm knows in what way competitors attract } \\
\text { customers. }\end{array}$ & .63 \\
\hline & $\begin{array}{l}\text { Inter-functional } \\
\text { coordination }\end{array}$ & $\begin{array}{l}\text { IFC1. Our firm's departments are collectively responsible for the } \\
\text { relationship with customers. }\end{array}$ & .67 \\
\hline & $(\mathrm{IFC})$ & $\begin{array}{l}\text { IFC2. Our firm's departments take decisions that affect the } \\
\text { relationship with customers collectively. }\end{array}$ & .89 \\
\hline & & $\begin{array}{l}\text { IFC3. Our firm's departments are collectively aware of the } \\
\text { importance of the relationship with customers. }\end{array}$ & .89 \\
\hline \multirow{13}{*}{$\begin{array}{l}\text { Service } \\
\text { innovation }\end{array}$} & \multirow{4}{*}{$\begin{array}{l}\text { Operation/ } \\
\text { delivery process } \\
\text { newness } \\
\text { (ODP) }\end{array}$} & $\begin{array}{l}\text { ODP1. The service required the installation of new software to } \\
\text { the company. }\end{array}$ & .62 \\
\hline & & $\begin{array}{l}\text { ODP } 2 . \text { The service required the installed of new hardware to the } \\
\text { company. }\end{array}$ & .71 \\
\hline & & ODP3. The service was supported by innovative technology. & .84 \\
\hline & & $\begin{array}{l}\text { ODP4. The service required a change in the customer's buying } \\
\text { behavior (e.g., way of buying and using it). }\end{array}$ & .82 \\
\hline & \multirow{3}{*}{$\begin{array}{l}\text { Service } \\
\text { modification } \\
(\mathrm{SM})\end{array}$} & $\begin{array}{l}\text { SM1. The service was a modification of an existing company } \\
\text { product. }\end{array}$ & .83 \\
\hline & & $\begin{array}{l}\text { SM2. The service was a revision of an existing company } \\
\text { product. }\end{array}$ & .84 \\
\hline & & $\begin{array}{l}\text { SM3. The service was a repositioning of an existing company } \\
\text { product. }\end{array}$ & .78 \\
\hline & \multirow{3}{*}{$\begin{array}{l}\text { Service newness } \\
\text { to the market } \\
(\mathrm{SNM})\end{array}$} & SNM1. The service was totally new to the market. & .81 \\
\hline & & $\begin{array}{l}\text { SNM2. The service offered new features versus competitive } \\
\text { products. }\end{array}$ & .71 \\
\hline & & $\begin{array}{l}\text { SNM3. The service required a change in the customer's buying } \\
\text { behavior(e.g., way of buying and using it). }\end{array}$ & 61 \\
\hline & \multirow{3}{*}{$\begin{array}{l}\text { Service newness } \\
\text { to the company } \\
\text { (SNC) }\end{array}$} & SNC 1 . The service was totally new to the company. & .73 \\
\hline & & $\begin{array}{l}\text { SNC } 2 \text {. The service allowed the company to enter a new market } \\
\text { for the first time. }\end{array}$ & 69 \\
\hline & & SNC3. The service created a new product line for the company. & .70 \\
\hline \multirow{5}{*}{$\begin{array}{l}\text { Business } \\
\text { performance }\end{array}$} & \multicolumn{2}{|c|}{$\begin{array}{l}\text { 1. Our firm has obtained profit (PFT) better than industry average over the past } 5 \\
\text { years. }\end{array}$} & .72 \\
\hline & \multicolumn{2}{|c|}{$\begin{array}{l}\text { 2. Our firm has achieved sales goal (SG) better than industry average over the past } \\
5 \text { years. }\end{array}$} & .79 \\
\hline & \multicolumn{2}{|c|}{$\begin{array}{l}\text { 3. Our firm has obtained quality (QLTY) better than industry average over the past } \\
5 \text { years. }\end{array}$} & .71 \\
\hline & \multicolumn{2}{|c|}{$\begin{array}{l}\text { 4. Our firm has achieved time to the market (TTM) faster than industry average } \\
\text { over the past } 5 \text { years. }\end{array}$} & .75 \\
\hline & \multicolumn{2}{|c|}{$\begin{array}{l}5 . \text { Our firm has offered inventory turn (IT) better than industry average over the past } \\
5 \text { years. }\end{array}$} & .70 \\
\hline
\end{tabular}

\section{Results}

\section{Direct effects analysis}

In this analysis, the numbers indicating all standardized regression and estimates of regression weights in each hypothesis are shown in Table 3 . The data analysis of the first hypothesis demonstrated that MKO was significantly and positively related to BIZ_PERF (loading $=.514, \mathrm{t}>1.96, p<$ $.01)$, supporting H1. Furthermore, the data analysis showed MKO was significantly related to SVC_INNO (loading = $.847, \mathrm{t}>1.96, p^{<} .001$ ), supporting $\mathrm{H} 2$. In verifying the hypothesis on SVC_INNO to BIZ_PERF, SVC_INNO was found to positively relate to BIZ_PERF (loading $=.532, \mathrm{t}>$ $1.96, p<.001)$. Therefore, H3 was also supported. 
Table 3: Standardized regression and estimates of regression weights

\begin{tabular}{|c|c|c|c|c|c|c|}
\hline \multirow[t]{2}{*}{ Hypothesis } & \multirow[t]{2}{*}{ Measure } & \multirow{2}{*}{$\begin{array}{l}\text { Standardized Regression } \\
\text { Weights }\end{array}$} & \multicolumn{3}{|c|}{$\begin{array}{l}\text { Estimates of regression } \\
\text { weights }\end{array}$} & \multirow[t]{2}{*}{ Findings } \\
\hline & & & S.E. & C.R. & $P$ & \\
\hline H1 & MKO --> BIZ_PERF & .514 & .227 & 4.200 & $* *$ & Supported \\
\hline $\mathrm{H} 2$ & MKO --> SVC_INNO & .847 & .249 & 6.915 & $* * *$ & Supported \\
\hline $\mathrm{H} 3$ & SVC_INNO --> BIZ_PERF & .532 & .101 & 4.816 & $* * *$ & Supported \\
\hline
\end{tabular}

Note: $* p<.05$ (two-tailed); $* * p<.01$ (two-tailed); ${ }^{* * *} p<.001$ (two-tailed); $N=260$

\section{Mediating effect and path analysis}

Focusing on the path coefficients between variables in the structural mode, the path analysis resulting in the mediation effect with statistical significance is shown in Table 4 . When examining the data, we found that the direct effect of MKO on BIZ_PERF was significant (loading $=.514, t>1.96, p$ $<.001)$, the indirect effect of MKO on SVC_INNO was significant (loading $=.847, \mathrm{t}>1.96, p<.001$ ), and
SVC_INNO on BIZ_PERF was also significant (loading $=.53 \overline{2}, \mathrm{t}>1.96, p<.001)$. The total effect of $\mathrm{MKO}$ on BIZ_PERF through SVC_INNO was increased (loading = $.964, t>1.96, p<.001)$. In testing the mediating effect of MKO on the relationships between SVC_INNO and BIZ_PERF, H4 was also found to be supported. Based on the argument of Baron and Kenny (1986), SVC_INNO partially mediated the relationship between MKO and BIZ_PERF.

Table 4: Estimate of standardized regression weights and effect analysis

\begin{tabular}{|c|c|c|c|c|c|}
\hline Measure & \multicolumn{5}{|c|}{ Standardized Regression Weights } \\
\hline \multirow{3}{*}{$\begin{array}{l}\text { MKO } \\
\text {->SVC_INNO } \\
\text {-> BIZ_PERF }\end{array}$} & Direct Effect & Indirect Effect & & & Total Effect \\
\hline & $\begin{array}{l}\text { MKO -> } \\
\text { BIZ_PERF }\end{array}$ & $\begin{array}{l}\text { MKO --> } \\
\text { SVC_INNO (A) }\end{array}$ & $\begin{array}{l}\text { SVC_INNO } \\
->\text { BIZ_PERF (B) }\end{array}$ & $\begin{array}{l}\text { Composite } \\
(\mathrm{C}=\mathrm{A} * \mathrm{~B})\end{array}$ & $\begin{array}{l}\text { MKO } \\
>\text { SVC_INNO } \\
\text {-> BIZ_PERF }\end{array}$ \\
\hline & .514 & .847 & .532 & .450 & .964 \\
\hline
\end{tabular}

Next, we tested whether the indirect (mediation) effect was statistically significant by using both the bootstrapping (Preacher \& Hayes, 2008) and PRODCLIN2 (MacKinnon, Williams \& Lockwood, 2007) methods. The intervals of bootstrapping bias-corrected 95\% CI indicated the lower (.109) and upper (.936) with $p<.001$, and percentile 95\% CI reflected the lower (.111) and the upper (.944) with $p<.001$ in Table 5 were significant. Moreover, MacKinnon 95\% CI reflected the lower (.125) and upper (.962) in Table 5, which also supported the mediating effect in $\mathrm{H} 4$ because $95 \% \mathrm{CI}$ did not contain the digit of 0 (MacKinnon et al., 2007). Consequently, $\mathrm{H} 4$ was supported.

Table 5: Bootstrapping and MacKinnon 95\% CI

\begin{tabular}{|c|c|c|c|c|c|c|c|c|}
\hline \multicolumn{9}{|c|}{ Indirect Effect Analysis } \\
\hline \multicolumn{6}{|c|}{ Bootstrapping } & \multicolumn{3}{|c|}{ MacKinnon 95\% CI } \\
\hline \multicolumn{3}{|c|}{ Bias-Corrected 95\% CI } & \multicolumn{3}{|c|}{ Percentile 95\% CI } & \multirow[t]{2}{*}{ Lower } & \multirow[t]{2}{*}{ Upper } & \multirow[t]{2}{*}{$P$} \\
\hline Lower & Upper & $P$ & Lower & Upper & $P$ & & & \\
\hline .109 & .936 & $* * *$ & .111 & .944 & $* * *$ & .125 & .962 & $* * *$ \\
\hline
\end{tabular}

\section{Empirical results}

\section{Market orientation and business performance}

As discussed, numerous studies have argued that firms considering the fulfillment of orders as a service that is highly valued by customers tend to have high competitiveness. In essence, services in every business transaction are becoming more dynamic and complex in the way that firms must change. Porter (2008) suggested that firms must identify their core capabilities to capitalize on market changes and outperform competitors. Specifically, firms that respond to market changes by using customer-driven capabilities tend to anticipate future market changes (Covin, Green, \& Slevin, 2006; Hart, 2006). By responding to customer needs and reviewing competitor activities, firms can create an ongoing innovative transition from products to services to capitalize on supply chain opportunities in the future.

Given the current market complexity, firms should coordinate among departments more collectively to use resources and then develop innovative services that customers perceive as satisfactory (Flint, Larsson, Gammelgaard \& Mentzer, 2005). Our findings are consistent with the assertion of Siguaw, Simpson and Enz (2006) that the benefits of innovation are improved services, fast turnaround, and increased business performance. Similarly, the argument of Cassiman and Veugelers (2006) supports our findings that greater innovation capability in knowledge acquisition and development by firms may create more value for customers. 
In addition, Lings (2004) suggested that a greater degree of market orientation that is based on innovation generates superior performance.

\section{Market orientation and service innovation}

Given supply chain competitiveness, developing a customerfocused service innovation capability is difficult. Any organization that lacks innovation cannot survive in a highly resilient market. Thus, firms tend to maximize their opportunities for survival and prosperity by integrating market orientation and service innovation (Stank et al., 2001; Vickery et al., 2003).

Thus, the ongoing efforts to increase the effectiveness of value chain operations through coordination among organizations have become crucial in business goal attainment (Kirca et al., 2004). In accordance with the study on learning by Calantone et al. (2002), who asserted that continual knowledge acquisition by an organization is incorporated, valued, and exploited tends to increase firm viability. Moreover, Nonaka and Konno (2005) asserted that the infinite cycle of knowledge acquisition, creation, and mobilization serves as an engine for firms to innovate and adapt faster to a continuously changing environment.

Furthermore, Lööf and Heshmati (2006) argued that firms with more knowledge of resource integration and risk flexibility are more likely to succeed in the market. An empirical study of Italian small- and medium-sized enterprises (SMEs) by Hall, Lotti and Mairesse (2009) further indicated that innovation is highly correlated with productivity and quality. More importantly, businesses using integrated innovation initiatives may have more market opportunities and higher performance than businesses that do not use these initiatives do.

In addition, Avlonitis et al. (2001) and Weerawardena (2003) proposed that customer-driven innovation can help firms create a strategy to synergize resources and improve business performance. Thus, we argue that firms' concentration of their business-specific knowledge on market orientation and subsequent linking of service innovation to order fulfillment is paramount to creating superior value for customers.

\section{Mediating effect of service innovation on the relationship between market orientation and business performance}

Andy Grove (Krames, 2004), the former Chairman of Intel Corporation, stated that successful firms must have more competitive strategies than rivals do and are marginalized if they do not. Christensen (2013) further suggested that innovation is critical to the long-term competitiveness and strategic goal achievement of a firm. In addition, businesses must attain superior performance and organizational sustainability through creativity and changes (Hult, Ketchen \& Arrfelt, 2007).
Our research echoes the study by Oke (2007), indicating that more firms have begun to focus intensively on value creation through innovation. This is supported by the study by Wolff and Pett (2006), who asserted that firms that innovate tend to have greater returns on investment. Moreover, according to their study of 466 SMEs in Italy, Francalanci and Morabito (2008) proposed that the integration of information systems might mediate firm absorptive capacity.

Our study results correspond to the findings of Brown et al. (2013) that optimizing quality and minimizing operational costs are the main objectives of businesses. Additionally, our argument is consistent with the statements of Kobayashi, Tamaki and Komoda (2003), who asserted that system integration can allow for the production of higher quality products and services with fewer resources. Moreover, market orientation among organizations resulting from interfirm cooperation can increase business performance (Kirca et al., 2005; Kotler, 2002).

According to the statistical evidence shown in Tables 3-5, service innovation mediates the relationship between market orientation and firm performance. Consequently, we argue that when firms increase innovative integration, they can improve service innovation in support of market orientation, yielding more value for customers and achieving higher financial performance.

\section{Managerial implications, recommendations, and future research}

The two main objectives of this study were achieved according to the cited studies and our arguments. We propose that firms should rapidly devise market-oriented strategies to outdistance competitors in the changing market. The following empirical highlights are the main contributions of our research to creating a wide range of valuable services for customers.

Among the three main components of market orientation analyzed in this study, the loading of Customer Orientation is the lowest (.56 compared with .73 for Competitor Orientation and .96 for Interfunctional Coordination). We assume that customer satisfaction should be prioritized over sales. More specifically, firms can create more business revenue when customers perceive service quality and agility to be high.

In addition, the loading of Service Modification was the lowest for service innovation (.55). When firms initiate modification or changes in service innovation, they require full cooperation and teamwork throughout the organization. Nevertheless, service innovation changes normally cause stress, distrust, and insecurity. Employees may have many reasons to fear these changes because of uncertainty and insecurity resulting from a lack of understanding regarding the rationale behind these changes. Thus, we recommend that firms engage in service modification only when employees are convinced of the value of customer orientation and are willing to change. 
Moreover, the loading of Inventory Turnover (.70) was revealed as the lowest among all factors associated with business performance in this study. Firms can create more sales and thus generate more revenue when inventory turnover is optimized compared with competitors with low inventory turnover. This result is reliable because 110 participating companies in this study $(42.31 \%$ of the total sample companies) were associated with manufacturing, and subsequently the manageability of inventory control is vital to supply chain business.

\section{Future research}

In this study, all data were derived post hoc from sample companies. Consequently, business strategies, cost containment, quality performance, and the service and inventory level in each organization were inherently difficult to analyze. Leadership and change management as well as goal achievement in each business may have influenced whether market orientation or service innovation was prioritized in the sample companies.

The infrastructure changes of supply chain operations have increased globally. Firms should understand how to use service innovation to support business performance more effectively. In addition to the problems addressed in this study regarding how to create service innovation and become competitive, we recommend that end-to-end market visibility, service agility solutions, and variability management in supply chains be studied further. Additionally, more studies on change management with regard to firm leadership and motivation to increase the value added through service innovation are highly recommended.

\section{References}

Avlonitis, G.J., Papastathopoulou, P.G. \& Gounaris, S.P. 2001. 'An empirically-based typology of product innovativeness for new financial services: success and failure scenarios', Journal of Product Innovation Management, 18(5): 324-342.

Bagozzi, R.P. \& Yi, Y. 1988. 'On the use of structural equation model in experimental designs', Journal of Marketing Research, 72(4): 271-284.

Baron, R.M. \& Kenny, D.A. 1986. 'The moderator-mediator variable distinction in social psychological research: Conceptual, strategic, and statistical considerations', Journal of Personality and Social Psychology, 51(6): 1173-1182.

Baruch, Y. \& Holtom, B.C. 2008. 'Survey response rate levels and trends in organizational research', Human Relations, 61(8): 11391160.

Bentler, P.M. 1992. EQS structural equations program manual, Los Angeles, CA: BMDP Statistical Software.

Berry, W.L., Whybark, D.C. \& Jacobs, F.R. 2005. Manufacturing planning and control for supply chain management. New York: McGraw-Hill/Irwin.

Bowersox, D.J., Closs, D.J. \& Cooper, M.B. 2002. Supply chain logistics management (Vol. 2). New York, NY: McGraw-Hill.
Brown, S., Blackmon, K., Cousins, P. \& Maylor, H. 2013. Operations management: policy, practice and performance improvement. London: Routledge.

Calantone, R.J., Cavusgil, S.T. \& Zhao, Y. 2002. 'Learning orientation, firm innovation capability, and firm performance', Industrial Marketing Management, 31(6): 515-524.

Cassiman, B. \& Veugelers, R. 2006. 'In search of complementarity in innovation strategy: internal $\mathrm{R} \& \mathrm{D}$ and external knowledge acquisition', Management Science, 52(1): 68-82.

Chapman, C.S. 2005. 'Not because they are new: Developing the contribution of enterprise resource planning systems to management control research', Accounting, Organizations and Society, 30(7): 685-689.

Chatterjee, S. \& Wernerfelt, B. 1991. 'The link between resources type of diversification: Theory and evidence', Strategic of Management Journal, 12(1): 33-48.

Chow, W.S., Madu, C.N., Kuei, C.H., Lu, M.H., Lin, C. \& Tseng, H. 2008. 'Supply chain management in the US and Taiwan: An empirical study', OMEGA, 36(5): 665-679.

Christensen, C. 2013. The innovator's dilemma: When new technologies cause great firms to fail. Boston, MA: Harvard Business Review Press.

Christopher, M. 2000. 'The agile supply chain: competing in volatile markets', Industrial Marketing Management, 29(1): 37-44.

Cohen, J.F. 2001. 'Environmental uncertainty and managerial attitude: Effects on strategic planning, non-strategic decisionmaking and organisational performance', South African Journal of Business Management, 32(3): 17-31.

Covin, J.G., Green, K.M. \& Slevin, D.P. 2006. 'Strategic process effects on the entrepreneurial orientation-sales growth rate relationship', Entrepreneurship Theory and Practice, 30(1): 57-81.

Cronbach, L.J. 1970. Essentials of psychological testing. (3rd ed.), New York, NY: Harper.

Daft, R.L. 1982. 'Bureaucratic versus nonbureaucratic structure and the process of innovation and change', Research in the Sociology of Organizations, 1: 129-166.

Damanpour, F. 1991. 'Organizational innovation: A meta-analysis of effects of determinants and moderators', Academy of Management Journal, 34(3): 555-590.

Dishman, P. \& Pearson, T. 2003. 'Assessing intelligence as learning within an industrial marketing group: A pilot study', Industrial Marketing Management, 32(7): 615-620.

Drucker, P.F. 2007. Management challenges for the 21st century. London: Routledge.

Eppinger, S.D. 2001. 'Innovation at the speed of information', Harvard Business Review, 79(1): 149-158.

Flint, D.J., Larsson, E., Gammelgaard, B. \& Mentzer, J.T. 2005. 'Logistics innovation: A customer value-oriented social process', Journal of Business Logistics, 26(1): 113-147. 
Francalanci, C. \& Morabito, V. 2008. 'IS integration and business performance: The mediation effect of organizational absorptive capacity in SMEs', Journal of Information Technology, 23(4): 297312.

Fruhling, A.L. \& Siau, K. 2007. 'Assessing organizational innovation capability and its effect on e-commerce initiatives', The Journal of Computer Information Systems, 47(4): 91-104.

Gainer, B. \& Padanyi, P. 2005. 'The relationship between marketoriented activities and market-oriented culture: Implications for the development of market orientation in nonprofit service organizations', Journal of Business Research, 58(6): 854-862.

Geringer, J.M., Tallman, S. \& Olsen, D.M. 2000. 'Product and international diversification among Japanese multinational firms', Strategic Management Journal, 21(1): 51-80.

Gray, B.J. \& Hooley, G.J. 2002. 'Guest editorial: Market orientation and service firm performance-a research agenda', European Journal of Marketing, 36(9/10): 980-989.

Green, J.R. \& Scotchmer, S. 1995. 'On the division of profit in sequential innovation', The RAND Journal of Economics, 26(1): 2033.

Grinstein, A. 2008. 'The effect of market orientation and its components on innovation consequences: a meta-analysis', Journal of the Academy of Marketing Science, 36(2): 166-173.

Hair, J.F., Rolph, E.A., Ronald, L.T. \& William, C.B. 1998. Multivariate data analysis. (5th ed.). New York, NY : Macmillan.

Hall, B.H., Lotti, F. \& Mairesse, J. 2009. 'Innovation and productivity in SMEs: empirical evidence for Italy', Small Business Economics, 33(1): 13-33.

Hart, M.L. 2006. 'Customer relationship management: Are software applications aligned with business objectives?', South African Journal of Business Management, 37(2): 17-32.

Homburg, C. \& Pflesser, C. 2000. 'A multiple-layer model of market-oriented organizational culture: Measurement issues and performance outcomes', Journal of Marketing Research, 37(4): 449462.

Hult, G.T.M. \& Ketchen, D.J. 2001. 'Does market orientation matter?: A test of the relationship between positional advantage and performance', Strategic Management Journal, 22(9): 899-906.

Hult, G.T.M., Ketchen, D.J. \& Arrfelt, M. 2007. 'Strategic supply chain management: Improving performance through a culture of competitiveness and knowledge development', Strategic Management Journal, 28(10): 1035-1052.

Jaworski, B.J. \& Kohli, A.K. 1996. 'Market orientation: Review, refinement, and roadmap', Journal of Market-Focused Management, 1(2): 119-135.

Jöreskog, K.G. \& Sörbom, D. 1996. LISREL 8 user's reference guide. Uppsala, Swede: Scientific Software International.

Kandampully, J. \& Duddy, R. 1999. 'Competitive advantage through anticipation, innovation and relationships', Management Decision, 37(1): 51-56.
Kirca, A.H., Jayachandran, S. \& Bearden, W.O. 2005. 'Market orientation: A meta-analytic review and assessment of its antecedents and impact on performance', Journal of Marketing, 69(2): 24-41.

Kobayashi, T., Tamaki, M. \& Komoda, N. 2003. 'Business process integration as a solution to the implementation of supply chain management systems', Information and Management, 40(8): 769780.

Kohli, A.K. \& Jaworski, B.J. 1990. 'Market orientation: The construct, research propositions, and managerial implications', The Journal of Marketing, 54(2): 1-18.

Kotler, P. 2002. Marketing places. New York, NY: Simon \& Schuster.

Krames, A.J. 2004. What the best CEOs know 7 exceptional leaders and their lessons for transforming any business. New York, NY: McGraw Hill.

Langerak, F., Hultink, E.J. \& Robben, H.S. 2004. 'The impact of market orientation, product advantage, and launch proficiency on new product performance and organizational performance', Journal of Product Innovation Management, 21(2): 79-94.

Lings, I.N. 2004. 'Internal market orientation: Construct and consequences', Journal of Business Research, 57(4): 405-413.

Lööf, H. \& Heshmati, A. 2006. 'On the relationship between innovation and performance: A sensitivity analysis', Economics of Innovation and New Technology, 15(4-5): 317-344.

Lukas, B.A. \& Ferrell, O.C. 2000. 'The effect of market orientation on product innovation', Journal of the Academy of Marketing Science, 28(2): 239-247.

MacKinnon, D.P., Fritz, M.S., Williams, J. \& Lockwood, C.M. 2007. 'Distribution of the product confidence limits for the indirect effect: Program PRODCLIN', Behavior Research Methods, 39(3): 384-389.

Matear, S., Osborne, P., Garrett, T. \& Gray, B.J. 2002. 'How does market orientation contribute to service firm performance? An examination of alternative mechanisms', European Journal of Marketing, 36(9/10): 1058-1075.

Moore, G.A. 2003. 'Darwin and the demon: innovating within established enterprises', Harvard Business Review, 82(7-8): 86-92.

Morgan, N.A., Vorhies, D.W. \& Mason, C.H. 2009. 'Market orientation, marketing capabilities, and firm performance', Strategic Management Journal, 30(8): 909-920.

Narver, J.C. \& Slater, S.F. 1990. 'The effect of a market orientation on business profitability', The Journal of Marketing, 54(4): 20-35.

Nonaka, I. \& Konno, N. 2005. "The concept of "5, 4": Building a foundation for knowledge creation', Knowledge Management: Critical Perspectives on Business and Management, 2(3): 53.

Oke, A. 2007. 'Innovation types and innovation management practices in service companies', International Journal of Operations and Production Management, 27(6): 564-587.

Porter, M.E. 2008. Competitive advantage: Creating and sustaining superior performance. New York: Simon and Schuster. 
Preacher, K.J. \& Hayes, A.F. 2008. 'Asymptotic and resampling strategies for assessing and comparing indirect effects in multiple mediator models', Behavior Research Methods, 40(3): 879-891.

Premkumar, G. \& King, W.R. 1994. 'Organizational characteristics and information systems planning: An empirical study', Information Systems Research, 5(2): 75-109.

Ramani, G. \& Kumar, V. 2008. 'Interaction orientation and firm performance', Journal of Marketing, 72(1), 27-45.

Rao, M.C. \& Rao, K.P. 2009. 'Inventory turnover ratio as a supply chain performance measure', Serbian Journal of Management, 4(1): 41-50.

Rodrigues, A.M., Stank, T.P. \& Lynch, D.F. 2004. 'Linking strategy, structure, process, and performance in integrated logistics', Journal of Business Logistics, 25(2): 65-94.

Siguaw, J.A., Simpson, P.M. \& Enz, C.A. 2006. 'Conceptualizing Innovation Orientation: A Framework for Study and Integration of Innovation Research', Journal of Product Innovation Management, 23(6): 556-574.

Slater, S.F. \& Narver, J.C. 1993. 'Product-market strategy and performance: an analysis of the Miles and Snow strategy types', European Journal of Marketing, 27(10): 33-51.

Stank, T.P., Keller, S.B. \& Daugherty, P.J. 2001. 'Supply chain collaboration and logistical service performance', Journal of Business Logistics, 22(1): 29-48.

Szymanski, D.M., Kroff, M.W. \& Troy, L.C. 2007. 'Innovativeness and new product success: insights from the cumulative evidence', Journal of the Academy of Marketing Science, 35(1): 35-52.

Teece, D.J. 2010. 'Business models, business strategy and innovation', Long Range Planning, 43(2): 172-194.

Vickery, S.K., Jayaram, J., Droge, C. \& Calantone, R. 2003. 'The effects of an integrative supply chain strategy on customer service and financial performance: an analysis of direct versus indirect relationships', Journal of Operations Management, 21(5): 523-539.

Wang, C.L. 2008. 'Entrepreneurial orientation, learning orientation, and firm performance', Entrepreneurship Theory and Practice, 32(4): 635-657.

Weerawardena, J. 2003. 'The role of marketing capability in innovation-based competitive strategy', Journal of Strategic Marketing, 11(1): 15-35.

Wolff, J.A. \& Pett, T.L. 2006. 'Small-firm performance: Modeling the role of product and process improvements', Journal of Small Business Management, 44(2): 268-284.

Zailani, S. \& Rajagopal, P. 2005. 'Supply chain integration and performance: US versus East Asian companies', Supply Chain Management: An International Journal, 10(5): 379-393.

Zhao, X., Flynn, B.B. \& Roth, A.V. 2007. 'Decision sciences research in China: Current status, opportunities, and propositions for research in supply chain management, logistics, and quality management', Decision Sciences, 38(1): 39-80.
Zhu, Q., Sarkis, J. \& Geng, Y. 2005. 'Green supply chain management in China: pressures, practices and performance', International Journal of Operations and Production Management, 25(5): 449-468. 
